\title{
Changes in miRNA expression and retinal blood vessels are associated with short-term air pollution exposure.
}

\author{
Tijs Louwies ${ }^{1 *}$, Luc Int Panis ${ }^{2}$, Patrick De Boever ${ }^{2}$, Tim Nawrot ${ }^{1}$ \\ From Methods in Epidemiology Symposium \\ Leuven, Belgium. 17 September 2015
}

Air pollution, a cardiovascular risk factor, might exert its effects through the microcirculation. Fundus photography allows study of the retinal vasculature in vivo. Short-term $\mathrm{PM}_{10}$ exposure is associated with changes in retinal blood vessels, but the underlying mechanism remains unknown. Expression of MIR21, MIR222 and MIR146A, gene regulators involved in oxidative stress and inflammatory processes, can be changed by air pollution and might be a pathway explaining the association between $\mathrm{PM}_{10}$ and microvascular changes.

50 healthy adults ( $50 \%$ women, $50 \%$ men, $23-58$ years old) were sampled once a month from December 2014 until April 2015. At each study visit fundus photos and venous blood samples were collected. $\mathrm{PM}_{10}$ data were obtained from a nearby monitoring station. Image analysis was used to calculate the width of retinal blood vessels, represented as the Central Retinal Arteriolar/Venular Equivalent (CRAE/CRVE). miRNA was isolated from blood and expression was measured using qRT-PCR. Mixed models were used for statistical analysis.

Short-term changes in $\mathrm{PM}_{10}$ exposure were associated with changes in CRAE, CRVE and miRNA-expression. Each $10 \mu \mathrm{g} / \mathrm{m}^{3}$ increase in $\mathrm{PM}_{10}$ during the previous 24 hours was associated with a $0.58 \mu \mathrm{m}$ decrease $(95 \% \mathrm{CI}$ : $-1.16,-0.0005 ; \mathrm{p}=0.056)$ in CRAE, a $0.99 \mu \mathrm{m}$ increase $(95 \%$ CI: $0.18,1.80 ; \mathrm{p}=0.021)$ in CRVE, a $6.6 \%$ decrease $(95 \%$ CI: -11.07, -2.17; $\mathrm{p}=0.0038)$ in miR-21 expression and a $6.7 \%$ decrease (95\% CI: $-10.70,-2.75 ; \mathrm{p}=0.0012)$ in miR-222 expression. miRNA expression was associated with CRAE and CRVE. Each 10\% increase in miR-21 expression and miR-222 was associated with respectively a $0.14 \mu \mathrm{m}$ increase (95\% CI: $0.0060,0.24 ; \mathrm{p}=0.046$ ) in CRAE

${ }^{1}$ Hasselt University, Diepenbeek, Belgium

Full list of author information is available at the end of the article and a $0.28 \mu \mathrm{m}$ decrease (95\% CI: $-0.50,-0.062 ; \mathrm{p}=0.016$ ) in CRVE.

$\mathrm{PM}_{10}$ exposure affects miRNAs involved in inflammation and oxidative stress. These changes may be an underlying mechanism for the association between $\mathrm{PM}_{10}$ exposure and retinal arteriolar narrowing and venular widening.

\section{Authors' details}

${ }^{1}$ Hasselt University, Diepenbeek, Belgium. ${ }^{2}$ Flemish Institute for Technological Research (VITO), Mol, Belgium.

Published: 17 September 2015

doi:10.1186/2049-3258-73-S1-P24

Cite this article as: Louwies et al:: Changes in miRNA expression and retinal blood vessels are associated with short-term air pollution exposure.. Archives of Public Health 2015 73(Suppl 1):P24.

Submit your next manuscript to BioMed Central and take full advantage of:

- Convenient online submission

- Thorough peer review

- No space constraints or color figure charges

- Immediate publication on acceptance

- Inclusion in PubMed, CAS, Scopus and Google Scholar

- Research which is freely available for redistribution

Submit your manuscript at www.biomedcentral.com/submit
() Biomed Central 